\title{
Role of Technology and Credit in Improving Farm Incomes in Rainfed Regions in Andhra Pradesh ${ }^{\$}$
}

\author{
C.A. Rama Rao ${ }^{a^{*}}$, Josily Samuela, Shalander Kumar ${ }^{\mathrm{b}}$, B.M.K. Raju ${ }^{\mathrm{a}}$, \\ Ravi Dupdal ${ }^{a}$ and B. Venkateswarlu ${ }^{\mathrm{c}}$
}

\author{
${ }^{a}$ Central Research Institute for Dryland Agriculture (CRIDA), Hyderabad - 500 059, Andhra Pradesh \\ 'International Crops Research Institute for the Semi-Arid Tropics (ICRISAT), \\ Patancheru - 502 324, Andhra Pradesh \\ ${ }^{c}$ V.N. Marathwada Krishi Vidyapeeth, Parbhani, Maharashtra
}

\begin{abstract}
Improving the productivity of rainfed agriculture and income of farmers is important to achieve sustainable and equitable growth. This paper has examined the role of technology and credit, the two important factors of agricultural growth, in increasing farm incomes using farm-level data from three rainfed districts, namely Adilabad, Mahabubnagar and Rangareddy of Andhra Pradesh for the year 2010-2011. For the study, optimum crop plans were developed in a linear programming framework, and the results have indicated considerable scope for enhancing farm incomes by re-allocation of resources, adoption of improved technologies and enhancing access to capital or credit. Improved technology could increase the net returns of farmers by 20-84 per cent, depending upon their farm categories in the study districts. In the absence of credit, the net returns declined up to 80 per cent, especially for small farmers. In the absence of credit, the suggested optimum farm plans are not income-maximizing, and were found to lead to inefficient use of resources, especially of land.
\end{abstract}

Key words: Rainfed agriculture, agricultural technology, credit, linear programming, Andhra Pradesh

JEL Classification: Q12, Q120

\section{Introduction}

In India, nearly sixty per cent of the net sown area is rainfed with little access to irrigation. Rainfed agriculture, often referred to as dryland agriculture, is practised in areas that are relatively warmer: arid, semiarid and dry-sub-humid- regions of the country. In these regions, the annual precipitation falls short of the potential evapo-transpiration demand. This together with lack of access to irrigation results in agriculture that is dependent on monsoon rains which are often

\footnotetext{
* Author for correspondence

Email: carrao@crida.in

$\S$ This paper is an output of National Agricultural Innovation Project (NAIP)-Component I sub-project "Policy and Institutional Options for Inclusive Agricultural Growth" funded by the Indian Council of Agricultural Research, New Delhi.
}

inadequate, erratic and undependable. Not only is the course of the monsoon during a season unpredictable, but also the inter-annual variation in the rainfall is high in these regions. Soils in the regions dominated by rainfed agriculture are highly degraded, low in fertility and are too shallow to hold moisture for long. The degraded soils and the short monsoon season (June to September) limit the crop growing period in most of the rainfed agriculture regions. This poses a severe constraint in terms of crops that can be grown successfully in these regions. Crops that take longer to maturity can only be grown with higher risk (Gaur and Kumawat, 2004; Rama Rao and Venkateswarlu, 2012). Though a number of technologies (e.g., Venkateswarlu et al., 2008) that can enhance productivity of rainfed crops have been developed by various research 
institutes, their adoption by farmers is less than desired levels resulting in significant gaps between the realizable and realized yields (Wani et al., 2009). The optimum use of natural resources like soil, and rain water along with use of improved crop varieties and chemical fertilizers holds the key to increasing productivity. Changing the land configuration through such techniques as ridge and furrow or broad bed and furrow, and adoption of farm ponds for harvesting and use of rain water are among the important technologies for a better management of natural resources and have been shown to be economically viable (Rama Rao et al., 2003).

One of the reasons for low adoption of technologies in the rainfed regions is inadequate awareness about the technology, economic viability and lack of easy access to credit. The demonstration of potential to enhance productivity and farm incomes is an important step in promoting a wider adoption of technologies. The development of dryland agriculture requires synergy across technologies, marketing systems, input supplies, credit, policies and institutions (Bantilan et al., 2006). This paper has examined how farm incomes can be improved through adoption of technologies in the selected rainfed districts of Andhra Pradesh. It has also examined the changes in capital requirement which is an important determinant of technology adoption. The augmentation of capital availability also leads to the question whether there is an opportunity to enhance farm income through better allocation of resources.

\section{The Study Area}

The study was undertaken in the three rainfed districts, namely Adilabad, Mahabubnagar and Rangareddy, of Andhra Pradesh. These districts represent a range of rainfall: Adilabad receives relatively higher annual rainfall $(983 \mathrm{~mm})$ and Mahabubnagar receives less rainfall $(749 \mathrm{~mm})$ (Kareemulla et al., 2007). These are backward districts with high incidence of poverty ${ }^{2}$ and unemployment ${ }^{3}$. The district of Adilabad has a net cropped area of 5.9 lakh ha, of which 78.5 per cent is rainfed. The cropping intensity in the district is relatively low at 107 per cent. The major crops grown in the district include cotton, soybean, sorghum, rice and pigeonpea. Sorghum has been continuously losing area to cotton, but soybean has started gaining ground in the recent years. The district of Mahabubnagar has a net cropped area of
7.75 lakh ha, of which 73 per cent is rainfed. The district is highly prone to droughts. The major crops grown in the district include maize, castor, rice and pigeon pea. The district has the highest livestock population across the districts selected for study. The district of Rangareddy is the most urbanized among the three selected districts. It faces a high frequency of droughts owing to erratic rainfall. The district has net cropped area of 2.29 lakh ha, of which 78 per cent is rainfed. The major crops grown are sorghum, rice, pigeonpea, cotton and castor. The cropping intensity in the district is about 111 per cent. In all the three districts, more than 45 per cent of the total farmers are marginal farmers (Kareemulla et al., 2007; http://agricoop.nic.in/).

\section{Data and Methodology}

The study is based on the primary data collected through a pre-tested schedule prepared specifically for the purpose. The general information about the sample farmers in these districts is given in the Table 1. The average farm-size was $1.90 \mathrm{ha}, 2.12$ ha and 1.97 ha for Adilabad, Mahabubnagar and Rangareddy districts,

Table 1. General information about the sample farmers in Adilabad, Mahabubnagar and Rangareddy districts of Andhra Pradesh

\begin{tabular}{|c|c|c|c|}
\hline Particulars & Adilabad & Mahabubnagar & Rangareddy \\
\hline Age (years) & 45 & 48 & 47 \\
\hline \multicolumn{4}{|c|}{ Education (\%) } \\
\hline Illiterates & 69 & 55 & 49 \\
\hline Matriculates & 47 & 48 & 55 \\
\hline Intermediates & 2 & 14 & 11 \\
\hline Graduates & 2 & 3 & 5 \\
\hline \multicolumn{4}{|c|}{ Caste (No.) } \\
\hline General & 2 & 36 & 22 \\
\hline OBCs & 34 & 45 & 56 \\
\hline $\mathrm{SCs} / \mathrm{STs}$ & 84 & 34 & 42 \\
\hline \multicolumn{4}{|c|}{ Occupation } \\
\hline Cropping & 120 & 120 & 120 \\
\hline Dairying & - & 5 & 28 \\
\hline Wage employment & it 92 & 107 & 75 \\
\hline \multicolumn{4}{|c|}{ Farm size (ha) } \\
\hline Rainfed & 1.88 & 1.91 & 1.85 \\
\hline Irrigated & 0.02 & 0.21 & 0.12 \\
\hline $\begin{array}{l}\text { Total operational } \\
\text { land }\end{array}$ & 1.90 & 2.12 & 1.97 \\
\hline
\end{tabular}


Rama Rao et al. : Role of Technology and Credit in Improving Farm Incomes in Rainfed Regions

respectively. The data on resource endowments, cropping pattern, input use and prices, credit, productivity levels, etc. for the agricultural year 201011 were obtained from a sample of 120 farmers from four villages in each selected district. These data were used to derive the input coefficients and the availability of different inputs and resources at the farm level. Table 2 and Appendix Tables 1 to 4 present the average resource requirements and net returns from different crops in the three selected districts.

To capture the technological change, data were obtained from different sources such as on-farm experiments conducted by the Central Research Institute for Dryland Agriculture (CRIDA) and the package of practices published by the State Agricultural University (CRIDA, 2008; 2009; 2010; ANGRAU, 2011). The input levels and productivity levels indicated therein represented the situation of technological change. The changes in technology were related to water management through rainwater harvesting, use of improved crop varieties and adoption of nutrient management. The impact of technology adoption and access to credit were examined following the linear programming framework (Rajendra et al., 1996; Sirohi and Gangwar, 1968). The following linear programming model was formulated:

$$
\operatorname{Maximize} \mathrm{Z}=\sum_{\mathrm{j}=1}^{\mathrm{n}} \mathrm{C}_{\mathrm{j}} \mathrm{X}_{\mathrm{j}}
$$

Subject to the following constraint:

$$
\sum_{j=1}^{n} a_{i j} x_{j} \leq b_{i}
$$

and the non-negativity constraints

where,

$\mathrm{Z}=$ Returns obtained,

$X_{j}=$ Level/area of the $j^{\text {th }}$ farm activity,

$\mathrm{n}=$ Number of possible activities,

$\mathrm{j}=1, \ldots . ., \mathrm{n}$,

$\mathrm{C}_{\mathrm{j}}=$ Net return over variable costs per unit (crops) of the $\mathrm{j}^{\text {th }}$ activity (₹/ha),

$a_{i j}=$ The quantity of the $i^{\text {th }}$ resource (land, labour, fertilizers, etc.) required to produce one unit of the $\mathrm{j}^{\text {th }}$ activity undertaken by a farmhousehold,

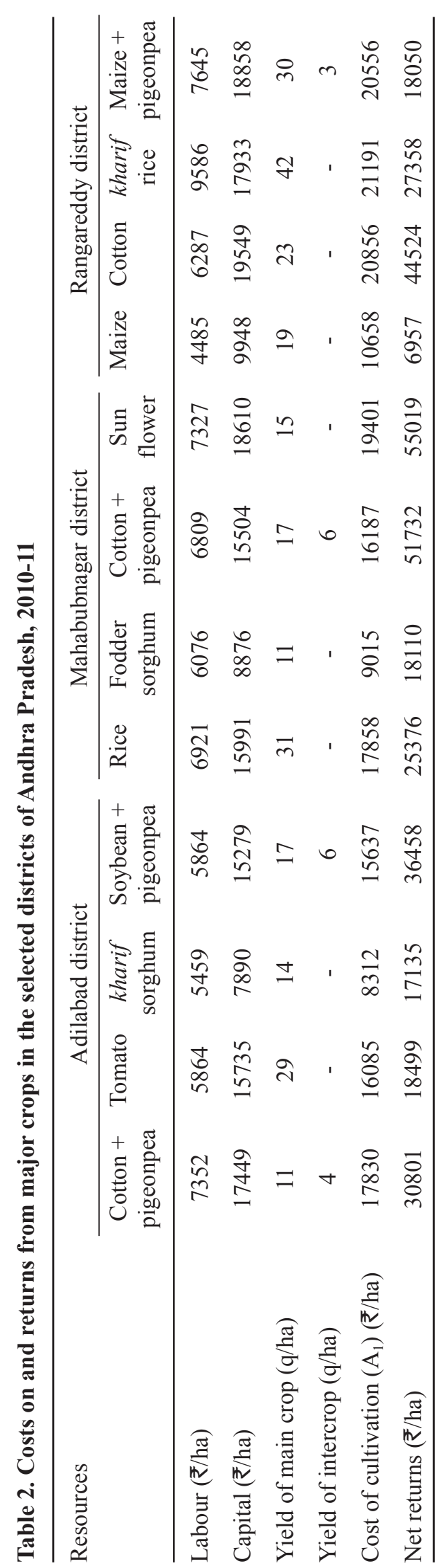


$\mathrm{m}=$ Number of resources;

$\mathrm{i}=1, \ldots, \mathrm{m}$,

$b_{i}=$ Amount of the $i^{\text {th }}$ resource available [land, human-days of labour (family and hired)] with a farm-household.

The objective was to find the cropping pattern that could yield the highest returns ' $Z$ ' and did not violate the constraints (Kaur et al., 2010; Mahendran et al., 2006). Separate land constrains were imposed for the kharif and rabi seasons and also for the irrigated area, wherever relevant. An option for leasing-out land was also included for the kharif season as very few farmers lease-out land during the rabi season. When a new technology was introduced through improved varieties, change in fertilizer application, and rain water harvesting, there was a change in the capital use. The activity-wise change in capital was introduced in the model while studying the impact of technology change. The net returns as affected by the adoption of improved technology, because of the yield increases and changes in costs, were also included in the optimization scheme.

The linear programming problem was solved by populating the model with appropriate coefficients to derive the optimum plans. Five plans were developed. Plan 1 represented the existing situation at current level of technology and credit. Plan 2 gave the optimum when the resources were optimally allocated along with the given technology and credit. Plan 3 represented the optimum plan when the farmer did not use any credit and operated within the limits of their own capital. The difference between Plan 2 and 3 indicated the impact of credit on the net returns. Then the change in optimum plan on adoption of improved technology was studied with credit (Plan 4) and without credit (Plan 5). In both Plans 2 and 4, the credit-use was limited to its current level. The analysis was performed for small ( $<2$ ha), medium (2-4 ha) and large ( $>4$ ha) farms in each of the selected districts. In the Adilabad district all the farmers had less than 3 ha land, therefore they were grouped into three equal groups and a representative farmer was chosen from each group.

\section{Results and Discussion}

To examine the impact of technology adoption and access to credit on the cropping pattern, income optimization was done and the results are presented below.

\section{Potential Income Gains from Technological and Policy Options}

\section{Adilabad District}

The cropping pattern under different optimum plans is given in Table 3.

\section{Small Farmers}

The small farmers (with 1.2 ha land) allocate about 67 per cent of their land to cotton + pigeonpea and the rest to kharif sorghum under the existing technology and credit situation. In Plan 2, when the available resources were optimally allocated, soybean +

Table 3. Farm-size-wise impact of credit and technology on the cropping pattern in Adilabad district of Andhra Pradesh

(in ha)

\begin{tabular}{|c|c|c|c|c|c|c|c|c|c|c|c|c|c|c|c|}
\hline \multirow[t]{2}{*}{ Crop } & \multicolumn{5}{|c|}{ Small farmers } & \multicolumn{5}{|c|}{ Medium farmers } & \multicolumn{5}{|c|}{ Large farmers } \\
\hline & $P_{1}$ & $\mathrm{P}_{2}$ & $\mathrm{P}_{3}$ & $\mathrm{P}_{4}$ & $\mathrm{P}_{5}$ & $\mathrm{P}_{1}$ & $\mathrm{P}_{2}$ & $\mathrm{P}_{3}$ & $\mathrm{P}_{4}$ & $\mathrm{P}_{5}$ & $\mathrm{P}_{1}$ & $\mathrm{P}_{2}$ & $\mathrm{P}_{3}$ & $\mathrm{P}_{4}$ & $\mathrm{P}_{5}$ \\
\hline Cotton + pigeonpea & 0.8 & 0.0 & 0.0 & 0.0 & 0.0 & 0.8 & 1.6 & 1.2 & 0.8 & 0.7 & 1.0 & 0.0 & 0.0 & 2.8 & 2.8 \\
\hline Kharif sorghum & 0.4 & 0.0 & 0.2 & 0.0 & 0.3 & 0.0 & 0.0 & 0.0 & 0.0 & 0.0 & 1.0 & 0.0 & 0.0 & 0.0 & 0.0 \\
\hline Soyabean + pigeonpea & 0.0 & 1.2 & 1.0 & 1.2 & 0.9 & 0.0 & 0.0 & 0.0 & 0.0 & 0.0 & 0.8 & 2.8 & 2.8 & 0.0 & 0.0 \\
\hline Kharif tomato & 0.0 & 0.0 & 0.0 & 0.0 & 0.0 & 0.8 & 0.0 & 0.0 & 0.8 & 0.8 & 0.0 & 0.0 & 0.0 & 0.0 & 0.0 \\
\hline Leased-out land (kharif) & 0.0 & 0.0 & 0.0 & 0.0 & 0.0 & 0.0 & 0.0 & 0.4 & 0.0 & 0.1 & 0.0 & 0.0 & 0.0 & 0.0 & 0.0 \\
\hline
\end{tabular}

Note: $\mathrm{P}_{1}$ : Existing situation, $\mathrm{P}_{2}$ : Optimum when the resources are optimally allocated within the given conditions of technology and credit, $\mathrm{P}_{3}$ : The optimum plan when farmers do not take any credit and operate within the limits imposed by the capital owned, $\mathrm{P}_{4}$ : Optimum with adoption of improved technology and with no credit constraint and $\mathrm{P}_{5}$ : Optimum with improved technology and without credit 
Rama Rao et al. : Role of Technology and Credit in Improving Farm Incomes in Rainfed Regions

pigeonpea emerged as the most profitable crop replacing cotton + pigeonpea and kharif sorghum. When investment was limited to owned capital, about 81 per cent of the area was allocated to soybean + pigeonpea and the rest to kharif sorghum (Plan 3). The levels of resource-use and net returns under these plans are given in Tables 6 and 7 for all the three districts. In the absence of borrowed capital, the small farmers could earn $₹ 42468$ as against $₹ 8016$ under the existing situation. It was attributable to the changes in cropping pattern. On removing the capital constraint completely (Plan 2), the income could be enhanced further to ₹ 49616. It was clear from the study that farmers were not allocating resources efficiently. Table 7 shows how the net returns change with the adoption of improved technologies. Access to credit could led to further income gains (Plan 4). These were higher than in Plan 3 which assumes access to borrowed capital but not to improved technology. The technology could enhance farm income by 22 per cent and it was inferred that access to credit and adoption of technology play a significant role in increasing farm income, especially for the small farmers.

\section{Medium farmers}

The medium farmers (with 1.6 ha land) currently allocate 50 per cent of their land to cotton + pigeonpea, and 50 per cent to tomato. In Plan 2 when resources were optimally allocated, whole of land was allocated to cotton + pigeonpea which increased net returns by 39 per cent. In Plan 3 when borrowed capital was not included, 75 per cent of the area was allocated to cotton + pigeonpea and the rest was leased-out. As can be seen from Table 6, in the absence of borrowed capital (Plan 3), the medium farmers earned up to $₹ 45633$ as against $₹ 35640$ under Plan 1 and the difference could be attributed to the change in cropping pattern and optimum allocation of resources. The removal of the capital constraint (Plan 2) led to still higher returns. Table 7 shows that with adoption of improved technology, half of the land was allocated to cotton + pigeonpea and tomato each. The income gains are much higher with about 81 per cent increase compared to the existing technology. When borrowed capital was assumed away, a farmer would be better-off if 0.11 ha of land is leased out even he adopts improved technology.

\section{Large farmers}

A large farmer (with 2.8 ha land) currently allocates 36 per cent each of his land to cotton + pigeonpea and kharif sorghum and 28 per cent to soybean + pigeonpea and could earn up to ₹ 94345. In Plan 2, when the resources were optimally allocated, soybean + pigeonpea emerged as a single most profitable crop and the net returns were found to increase by 30 per cent. The Plan 3 with the absence of borrowed capital, did not show any change in the cropping pattern and net returns (Tables 3 and 6). Under Plan 4 with adoption of improved technology, cotton+ pigeonpea emerged as the most profitable crop. The adoption of improved technology increased the net returns by 36 per cent from the existing returns.

\section{Mahabubnagar District}

The optimum plans for the three categories of farmers in the Mahabubnagar district were derived under the varying situations of credit and technology and are depicted in Table 4.

\section{Small Farmers}

A small farmer currently allocates nearly 67 per cent of his land to cotton, 22 per cent to kharif rice, and 11 per cent to rabi sorghum. The net returns increased only marginally $(0.7 \%)$ with the reorganization of available resources optimally (Plan 2 ), indicating that the farmers were operating efficiently. Under Plan 2, the limiting factor was availability of hired labour. The Plan 3 provided net returns which were about 73 per cent less than in the existing situation, as the capital available with the farmer after deducting the credit availed was only ₹ 2148 . It is evident that the farmer had to lease out 74 per cent of his land in the absence of borrowed capital and in this case, the limiting factor was capital. With the adoption of improved technology and addressal of capital constraint, 67 per cent of the cropped area was allocated to cotton, 22 per cent to kharif rice and 11 per cent to rabi sorghum and it gave net return which was about 35 per cent more than the income under Plan 1. When borrowed capital was assumed away in Plan 5, the farmer had only ₹ 1771 for cultivation, a considerable part $(64 \%)$ of his land was leased-out owing to scarcity of capital. Cotton and kharif rice were each allocated 13 per cent land and rabi sorghum was 
Table 4. Farm-size-wise impact of credit and technology on the cropping pattern in Mahabubnagar district of Andhra Pradesh

(in ha)

\begin{tabular}{|c|c|c|c|c|c|c|c|c|c|c|c|c|c|c|c|}
\hline \multirow[t]{2}{*}{ Crop } & \multicolumn{5}{|c|}{ Small farmers } & \multicolumn{5}{|c|}{ Medium farmers } & \multicolumn{5}{|c|}{ Large farmers } \\
\hline & $\mathrm{P}_{1}$ & $\mathrm{P}_{2}$ & $\mathrm{P}_{3}$ & $\mathrm{P}_{4}$ & $\mathrm{P}_{5}$ & $\mathrm{P}_{1}$ & $\mathrm{P}_{2}$ & $\mathrm{P}_{3}$ & $\mathrm{P}_{4}$ & $\mathrm{P}_{5}$ & $\mathrm{P}_{1}$ & $\mathrm{P}_{2}$ & $\mathrm{P}_{3}$ & $\mathrm{P}_{4}$ & $\mathrm{P}_{5}$ \\
\hline Kharif cotton & 1.2 & 1.3 & 0.3 & 1.2 & 0.3 & 0.0 & 0.0 & 0.0 & 0.0 & 0.0 & 0.0 & 0.0 & 0.0 & 0.0 & 0.0 \\
\hline Kharif maize & 0.0 & 0.0 & 0.0 & 0.0 & 0.0 & 1.2 & 0.0 & 0.0 & 0.0 & 0.0 & 2.0 & 0.0 & 0.0 & 0.0 & 0.0 \\
\hline Kharif rice & 0.4 & 0.0 & 0.0 & 0.4 & 0.3 & 0.0 & 0.0 & 0.0 & 0.0 & 0.0 & 1.2 & 0.0 & 0.0 & 1.1 & 0.4 \\
\hline Rabi sorghum & 0.2 & 0.2 & 0.2 & 0.2 & 0.2 & 0.0 & 0.0 & 0.0 & 0.0 & 0.0 & 0.0 & 0.0 & 0.0 & 0.0 & 0.0 \\
\hline Cotton + Pigeonpea & 0.0 & 0.0 & 0.0 & 0.0 & 0.0 & 2.0 & 2.4 & 2.4 & 2.4 & 1.7 & 4.0 & 6.7 & 4.1 & 6.0 & 5.7 \\
\hline Rabi sunflower & 0.0 & 0.0 & 0.0 & 0.0 & 0.0 & 1.2 & 1.2 & 0.0 & 1.2 & 1.2 & 0.0 & 0.0 & 0.0 & 0.0 & 0.0 \\
\hline Rabi groundnut & 0.0 & 0.0 & 0.0 & 0.0 & 0.0 & 0.0 & 0.0 & 0.0 & 0.0 & 0.0 & 0.8 & 0.0 & 0.0 & 0.0 & 0.0 \\
\hline Leased-out land (kharif) & 0.0 & 0.3 & 1.3 & 0.0 & 1.3 & 0.0 & 0.8 & 0.8 & 0.8 & 1.5 & 0.0 & 0.5 & 3.1 & 0.1 & 1.2 \\
\hline Rabi fallow & 0.0 & 0.0 & 0.0 & 0.0 & 0.0 & 0.0 & 0.0 & 1.2 & 0.0 & 0.0 & 0.0 & 0.0 & 0.0 & 0.0 & 0.0 \\
\hline
\end{tabular}

Note: $\mathrm{P}_{1}$ : Existing situation, $\mathrm{P}_{2}$ : Optimum when the resources are optimally allocated within the given conditions of technology and credit, $\mathrm{P}_{3}$ : The optimum Plan when farmers do not take any credit and operate within the limits imposed by the capital owned, $\mathrm{P}_{4}$ : Optimum with adoption of improved technology and with no credit constraint and $\mathrm{P}_{5}$ : Optimum with improved technology and without credit

allocated 10 per cent land. Thus, lack of access to credit is an important impediment to achieving higher farm income.

\section{Medium Farmers}

A medium farmer currently allocates 46 per cent of his land to cotton + pigeonpea and 27 per cent each to rabi sunflower and kharif maize. Under Plan 1, a medium farmer could get net returns of ₹ 161750 because cotton + pigeonpea and sunflower gave higher returns (Tables 4 and 6). Under Plan 2, when resources were optimally allocated, the kharif maize was replaced with increase in the area under cotton + pigeonpea $(54 \%)$, sunflower $(27 \%)$ and the remaining was leasedout $(19 \%)$. The net returns increased in the optimum Plan by 14 per cent over the existing situation and the limiting factor was hired labour. Under Plan 3, when borrowed capital was not included, the net returns were reduced by 30 per cent as the borrowed capital of the farmer was 58 per cent of the total capital used. The farmer was forced to lease-out because capital was a limiting factor. Under Plan 4 with access to improved technology and credit, 54 per cent of land was allocated to cotton + pigeonpea, 27 per cent to rabi sunflower and about 19 per cent land was leased-out. Though area was leased-out, the net returns from Plan 4 increased by 17.2 per cent compared to Plan 1 (Table 7).

\section{Large Farmers}

The existing cropping pattern of a large farmer with 7.2 ha land included cotton+ pigeonpea (50\%), kharif maize $(25 \%)$, kharif rice $(15 \%)$ and rabi groundnut (10\%). Under Plan 2, cotton + pigeonpea emerged as the single most profitable crop and it was found better to lease-out the rest (7\%) of the land since capital was observed to be the limiting factor (Table 4) with 25 per cent increase in the net returns. Under the Plan 3, it was optimum to lease-out 43 per cent of the land and the net returns declined by 37.3 per cent compared to the optimum Plan (Table 6). In Plan 4, about 84 per cent of the land was allocated to cotton + pigeonpea, 15 per cent to kharif rice and 1 per cent was leasedout. The net returns obtained under this Plan increased by 41.4 per cent over the existing plan. And under Plan 5 when credit was restricted, 78 per cent of the area was allocated to cotton + pigeonpea, 5 per cent to rice and 16 per cent was leased-out.

\section{Rangareddy District}

The optimum plans for the three categories of farmers in the Rangareddy district were derived under the varying situations of credit and technology and are depicted in Table 5. 
Rama Rao et al. : Role of Technology and Credit in Improving Farm Incomes in Rainfed Regions

Table 5. Farm-size-wise impact of credit and technology on the cropping pattern in Rangareddy district of Andhra Pradesh

(in ha)

\begin{tabular}{|c|c|c|c|c|c|c|c|c|c|c|c|c|c|c|c|}
\hline \multirow[t]{2}{*}{ Crop } & \multicolumn{5}{|c|}{ Small farmers } & \multicolumn{5}{|c|}{ Medium farmers } & \multicolumn{5}{|c|}{ Large farmers } \\
\hline & $\mathrm{P}_{1}$ & $\mathrm{P}_{2}$ & $\mathrm{P}_{3}$ & $\mathrm{P}_{4}$ & $\mathrm{P}_{5}$ & $\mathrm{P}_{1}$ & $\mathrm{P}_{2}$ & $\mathrm{P}_{3}$ & $\mathrm{P}_{4}$ & $\mathrm{P}_{5}$ & $\mathrm{P}_{1}$ & $\mathrm{P}_{2}$ & $\mathrm{P}_{3}$ & $\mathrm{P}_{4}$ & $\mathrm{P}_{5}$ \\
\hline Kharif maize + Pigeonpea & 0.4 & 0.0 & 0.0 & 0.0 & 0.0 & 0.4 & 0.0 & 0.0 & 0.0 & 0.0 & 0.0 & 0.0 & 0.0 & 0.0 & 0.0 \\
\hline Cotton & 0.8 & 1.6 & 0.2 & 1.6 & 0.2 & 1.6 & 2.0 & 0.3 & 2.0 & 0.3 & 0.0 & 3.5 & 0.0 & 2.8 & 0.0 \\
\hline Kharif rice & 0.4 & 0.0 & 0.0 & 0.0 & 0.0 & 0.2 & 0.0 & 0.0 & 0.0 & 0.0 & 2.4 & 0.0 & 0.0 & 0.0 & 0.0 \\
\hline Rabi rice & 0.2 & 0.2 & 0.0 & 0.2 & 0.0 & 0.0 & 0.0 & 0.0 & 0.0 & 0.0 & 1.6 & 0.6 & 0.0 & 1.6 & 0.0 \\
\hline Kharif maize & 0.0 & 0.0 & 0.0 & 0.0 & 0.0 & 0.0 & 0.0 & 0.0 & 0.0 & 0.0 & 1.6 & 0.0 & 0.0 & 0.0 & 0.0 \\
\hline $\begin{array}{l}\text { Kharif sorghum + } \\
\text { Pigeonpea }\end{array}$ & 0.0 & 0.0 & 0.0 & 0.0 & 0.0 & 0.0 & 0.0 & 0.0 & 0.0 & 0.0 & 1.6 & 2.1 & 4.2 & 2.0 & 4.2 \\
\hline Leased-out land (kharif) & 0.0 & 0.0 & 1.4 & 0.0 & 1.4 & 0.0 & 0.0 & 1.9 & 0.2 & 2.0 & 0.0 & 0.0 & 1.4 & 0.8 & 1.4 \\
\hline Rabi fallow & 0.0 & 0.0 & 0.2 & 0.0 & 0.2 & 0.0 & 0.2 & 0.0 & 0.0 & 0.0 & 0.0 & 1.0 & 1.6 & 0.0 & 1.6 \\
\hline
\end{tabular}

Note: $\mathrm{P}_{1}$ : Existing situation, $\mathrm{P}_{2}$ : Optimum when the resources are optimally allocated within the given conditions of technology and credit, $\mathrm{P}_{3}$ : The optimum Plan when farmers do not take any credit and operate within the limits imposed by the capital owned, $\mathrm{P}_{4}$ : Optimum with adoption of improved technology and with no credit constraint and $\mathrm{P}_{5}$ : Optimum with improved technology and without credit

\section{Small Farmers}

A small farmer currently allocates his land to cotton $(45 \%)$, maize + pigeonpea $(22 \%)$, rabi rice $(11 \%)$ and kharif rice $(22 \%)$. In Plan 2, with the existing technology, 89 per cent of the total area was allocated to cotton and rest to rabi rice. The income from this plan increased by 27.8 per cent over the existing situation. Limitation of capital availability was found to lead to a severe restriction on what can be grown as is evident from Plan 3, wherein 79 per cent of land was leased-out leading to 82 per cent reduction in the income of a small farmer. With the adoption of improved technologies (Plan 4), there was 44 per cent increase in the income (Table 7). The credit availed by a small farmer was nearly 90 per cent of his capital use and if it was removed from the resource availability, there was a significant reduction in the achievable returns.

\section{Medium Farmers}

A medium farmer currently allocates land to cotton $(73 \%)$, kharif rice $(9 \%)$ and kharif maize + pigeonpea (18\%). In Plan 2, cotton emerged as the single most profitable crop and the net returns obtained were ₹ 103876 . Under Plan 3, about 88 per cent of the land was leased-out and the remaining 12 per cent was allocated to cotton. The net return obtained was ₹ 19124
(Tables 5 and 6). Under Plan 4, with the adoption of improved technology, cotton emerged as the sole profitable crop and leasing-out land was 8 per cent. When a medium farmer was assumed to rely on owned capital without any borrowed capital in Plan 5, it was optimum to allocate sorghum + pigeonpea to leaseout. No rabi cropping was observed.

\section{Large Farmers}

A large farmer currently allocates land to kharif rice (34\%), kharif maize, rabi rice and kharif sorghum + pigeonpea (22\% each) and could earn a net return of ₹ 189189 from 5.6 ha of land (Plan 1). Under the Plan 2 , when the available resources were optimally allocated, cotton (48\%), rabi rice (9\%), kharif sorghum + pigeonpea (29\%) and fallow land (14\%) emerged as the profitable cropping pattern. Under Plan 3 which assumes no borrowed capital, about 58 per cent of the land was allocated to kharif sorghum + pigeonpea, and 20 per cent of the land was leased-out with no crop being grown during rabi. Under Plan 4 and Plan 5, when improved technology was adopted, even with credit restriction, a large farmer could get higher returns than in the existing situation with 84.8 per cent increase in the net returns (Tables 5 and 7). The findings also suggest that it is more profitable to grow fewer crops to the extent the resources permit and it is in line with 
Table 6. Effect of access to credit on net returns in the selected districts of Andhra Pradesh across different categories of farmers under different plans

(per farm)

\begin{tabular}{|c|c|c|c|c|c|c|c|c|c|}
\hline \multirow[t]{2}{*}{ Resource } & \multicolumn{3}{|c|}{ Plan 1: $\mathrm{P}_{1}$} & \multicolumn{3}{|c|}{ Plan 2: $\mathrm{P}_{2}$} & \multicolumn{3}{|c|}{ Plan 3: $\mathrm{P}_{3}$} \\
\hline & $\begin{array}{c}\text { Small } \\
\text { farmers }\end{array}$ & $\begin{array}{l}\text { Medium } \\
\text { farmers }\end{array}$ & $\begin{array}{c}\text { Large } \\
\text { farmers }\end{array}$ & $\begin{array}{c}\text { Small } \\
\text { farmers }\end{array}$ & $\begin{array}{l}\text { Medium } \\
\text { farmers }\end{array}$ & $\begin{array}{l}\text { Large } \\
\text { farmers }\end{array}$ & $\begin{array}{c}\text { Small } \\
\text { farmers }\end{array}$ & $\begin{array}{l}\text { Medium } \\
\text { farmers }\end{array}$ & $\begin{array}{c}\text { Large } \\
\text { farmers }\end{array}$ \\
\hline \multicolumn{10}{|c|}{ Adilabad district } \\
\hline Capital (₹) & 12109 & 22030 & 42431 & 8147 & 13150 & 17816 & 6786 & 9945 & 17816 \\
\hline Family labour (humandays) & 93 & 87 & 296 & 43 & 67 & 104 & 44 & 51 & 104 \\
\hline Hired labour, (humandays) & 56 & 78 & 134 & 24 & 21 & 56 & 23 & 16 & 56 \\
\hline Kharif land (ha) & 1.2 & 1.6 & 2.8 & 1.2 & 1.6 & 2.8 & 1.2 & 1.21 & 2.8 \\
\hline Net returns (₹) & 8016 & 35640 & 94346 & 49616 & 58874 & 134988 & 42468 & 45633 & 134988 \\
\hline \multicolumn{10}{|c|}{ Mahabubnagar district } \\
\hline Capital (₹) & 10500 & 23691 & 46110 & 9076 & 22620 & 46083 & 2148 & 13685 & 28269 \\
\hline Family labour (humandays) & 107 & 135 & 330 & 54 & 56 & 101 & 17 & 36 & 62 \\
\hline Hired labour (humandays) & 39 & 70 & 192 & 39 & 70 & 188 & 8 & 52 & 115 \\
\hline Kharif land (ha) & 1.60 & 3.20 & 7.20 & 1.34 & 2.36 & 7.20 & 0.27 & 2.38 & 7.20 \\
\hline Rabi land (ha) & 0.20 & 1.20 & 0.80 & 0.20 & 1.20 & 0.00 & 0.20 & 0.00 & 0.00 \\
\hline Net returns (₹) & 55703 & 161750 & 239677 & 56295 & 188516 & 325740 & 16885 & 132682 & 203995 \\
\hline \multicolumn{10}{|c|}{ Rangareddy district } \\
\hline Capital (₹) & 16580 & 18874 & 31790 & 16277 & 17200 & 31790 & 1580 & 2207 & 9123 \\
\hline Family labour (humandays ) & 52 & 67 & 145 & 52 & 41 & 145 & 5 & 5 & 122 \\
\hline Hired labour (humandays) & 68 & 81 & 223 & 61 & 81 & 147 & 6 & 10 & 88 \\
\hline Kharif land (ha) & 1.6 & 2.2 & 5.6 & 1.6 & 2.0 & 5.6 & 1.6 & 2.2 & 5.6 \\
\hline Rabi land (ha) & 0.2 & 0 & 1.6 & 0.2 & 0 & 0.6 & 0.0 & 0 & 0.0 \\
\hline Net returns (₹) & 46205 & 97995 & 189189 & 63913 & 103876 & 244228 & 11122 & 19124 & 139454 \\
\hline
\end{tabular}

Note: $\mathrm{P}_{1}$ : Existing situation, $\mathrm{P}_{2}$ : Optimum when the resources are optimally allocated within the given conditions of technology and credit, $\mathrm{P}_{3}$ : The optimum plan when farmers do not take any credit and operate within the limits imposed by the capital owned

those reported, for example, by Kaur et al. (2010) and Varalakshmi (2007). The income stabilizing effects of a more diversified cropping pattern can be examined only in a multi-year analysis of a given farm.

\section{Summary and Conclusions}

The study has shown that significant increases in the net returns are possible with adoption of improved technology. Credit has been found to play a crucial role in technology adoption and income growth, especially for small farmers. There is scope to increase the farm income with better allocation of resources even with the existing technology. A major source of the capital for a small farmer is credit taken from various sources. When availability of capital gets restricted, it is better for a farmer to lease-out part of his land than to cultivate. In Adilabad district with adoption of improved technology, cotton + pigeonpea has appeared to be most profitable in the case of medium and large farmers, whereas for small farmers, soybean + pigeonpea has been found profitable. In the case of small and large farmers, soybean + pigeonpea has been found to be most profitable under the assumption of no credit. It is thus clear that adoption of improved technologies along with proper reallocation of resources can raise farm incomes considerably.

In the district of Mahabubnagar, when use of credit was not assumed, farmers had to lease-out their land and with adoption of improved technology net returns was found to increase. It has also been shown that availability of credit is an important enabling factor in increasing the farm incomes. In Rangareddy district, 
Rama Rao et al. : Role of Technology and Credit in Improving Farm Incomes in Rainfed Regions

Table 7. Effect of improved technologies on net returns in the selected districts of Andhra Pradesh across different categories of farmers under different plans

(per farm)

\begin{tabular}{|c|c|c|c|c|c|c|c|c|c|}
\hline \multirow[t]{2}{*}{ Resource } & \multicolumn{3}{|c|}{ Plan 1: $\mathrm{P}_{1}$} & \multicolumn{3}{|c|}{ Plan 4: $\mathrm{P}_{4}$} & \multicolumn{3}{|c|}{ Plan 5: $\mathrm{P}_{5}$} \\
\hline & $\begin{array}{c}\text { Small } \\
\text { farmers }\end{array}$ & $\begin{array}{l}\text { Medium } \\
\text { farmers }\end{array}$ & $\begin{array}{c}\text { Large } \\
\text { farmers }\end{array}$ & $\begin{array}{c}\text { Small } \\
\text { farmers }\end{array}$ & $\begin{array}{l}\text { Medium } \\
\text { farmers }\end{array}$ & $\begin{array}{l}\text { Large } \\
\text { farmers }\end{array}$ & $\begin{array}{c}\text { Small } \\
\text { farmers }\end{array}$ & $\begin{array}{l}\text { Medium } \\
\text { farmers }\end{array}$ & $\begin{array}{l}\text { Large } \\
\text { farmers }\end{array}$ \\
\hline \multicolumn{10}{|c|}{ Adilabad district } \\
\hline Capital (₹) & 12109 & 22030 & 42431 & 7222 & 11174 & 23716 & 5840 & 10234 & 23716 \\
\hline Family labour (humandays ) & 93 & 87 & 296 & 43 & 43 & 100 & 44 & 39 & 100 \\
\hline Hired labour (humandays) & 56 & 78 & 134 & 24 & 39 & 42 & 23 & 38 & 42 \\
\hline Kharif land (ha) & 1.2 & 1.6 & 2.8 & 1.2 & 1.6 & 2.8 & 1.2 & 1.5 & 2.8 \\
\hline Net returns (₹) & 8016 & 35640 & 94345 & 60799 & 82862 & 147596 & 50334 & 78751 & 147596 \\
\hline \multicolumn{10}{|c|}{ Mahabubnagar district } \\
\hline Capital ('/ha) & 10500 & 23690 & 46110 & 10104 & 22980 & 52439 & 1771 & 18182 & 46110 \\
\hline Family labour (humandays ) & 107 & 135 & 330 & 68 & 56 & 109 & 22 & 45 & 91 \\
\hline Hired labour (humandays) & 39 & 70 & 192 & 39 & 70 & 192 & 3 & 55 & 165 \\
\hline Kharif land (ha) & 1.60 & 3.20 & 7.20 & 1.6 & 3 & 7 & 1.6 & 3 & 7.2 \\
\hline Rabi land (ha) & 0.20 & 1.20 & 0.80 & 0.2 & 1 & 0 & 0.2 & 1 & 0 \\
\hline Net returns (₹) & 55703 & 161750 & 245599 & 75445 & 226617 & 419095 & 32523 & 183103 & 267313 \\
\hline \multicolumn{10}{|c|}{ Rangareddy district } \\
\hline Capital (₹/ha) & 16580 & 18874 & 31790 & 16239 & 17200 & 31790 & 1483 & 2106 & 9123 \\
\hline Family labour (humandays ) & 52 & 67 & 145 & 52 & 41 & 145 & 4 & 5 & 122 \\
\hline Hired labour (humandays) & 68 & 81 & 223 & 61 & 81 & 159 & 6 & 10 & 88 \\
\hline Kharif land (ha) & 1.6 & 2.2 & 5.6 & 1.6 & 2.2 & 5.6 & 1.6 & 2.2 & 5.6 \\
\hline Rabi land (ha) & 0.2 & 0 & 1.6 & 0.2 & 0 & 1.6 & 0.0 & 0 & 0.0 \\
\hline Net returns (₹) & 46205 & 97995 & 189189 & 115080 & 133005 & 451366 & 15492 & 22077 & 361368 \\
\hline
\end{tabular}

Note: $\mathrm{P}_{1}$ : Existing situation, $\mathrm{P}_{4}$ : Optimum with adoption of improved technology and with no credit constraint, and $\mathrm{P}_{5}$ : Optimum with improved technology and without credit

limitation on availability of capital has been found to lead to a severe restriction on what can be grown and it led to 82 per cent reduction in the income of a small farmer. For a medium farmer, though no considerable changes in the cropping pattern were observed, income was found to increase by 36 per cent with improved technology and access to credit. Therefore, continued efforts are required to make technology dissemination more effective and efficient and to make credit more accessible to the farmers.

\section{End-Notes}

1. Rainfed districts are those districts where the evapotranspiration is more than the annual rainfall and the net irrigated area is relatively less. Climatically, districts with arid, semi-arid and dry sub-humid climate are considered as the rainfed regions if they do not have access to irrigation (Wani et al., 2009)

2. The incidence of rural poverty in Adilabad and Mahabubnagar districts was 26.1 per cent and 11.8 per cent, respectively and it was higher than the state average (Chaudhuri and Gupta, 2009).

3. The percentage of non-workers in total population is 54.8 per cent in Mahabubnagar district, 59 per cent in Rangareddy district and 48.1 per cent in Adilabad district and the state average is 54.2 per cent (DES, 2007).

4. In fact, optimization plan allocated all the land to tomato. As tomato crop is often prone to price risks, restriction was imposed in the model to only 50 per cent of the land. 


\section{Acknowledgement}

Authors are thankful to the anonymous reviewer for his valuable comments.

\section{References}

ANGRAU (Acharya NG Ranga Agricultural University) (2011) Vyavasaya Panchangam 2009-2010, Hyderabad.

Bantilan, M.C.S., Anand Babu, P., Anupama, G.V., Deepthi, H. and Padmaja, R. (2006) Dryland agriculture: Dynamics, challenges and priorities. Research Bulletin No. 20. International Crops Research Institute for Semi Arid Tropics (ICRISAT), Hyderabad.

Chaudhuri, S. and Gupta, N. (2009) Levels of living and poverty patterns: A district-wise analysis for India. Economic and Political Weekly, XLIV (9): 94-110.

CRIDA (Central Research Institute for Dryland Agriculture) (2008) Annual Report 2007-08, Hyderabad. 162p.

CRIDA(Central Research Institute for Dryland Agriculture) (2009) Sustainable rural livelihoods through enhanced farming systems productivity and efficient support systems in rainfed areas (NAIP) Annual Report 2008, $60 \mathrm{p}$.

CRIDA (Central Research Institute for Dryland Agriculture) (2010) Sustainable rural livelihoods through enhanced farming systems productivity and efficient support systems in rainfed areas (NAIP) Annual Report 2010, $46 \mathrm{p}$.

DES (Directorate of Economics and Statistics) (2007) Statistical Abstract of Andhra Pradesh, Government of Andhra Pradesh, Hyderabad.

Kareemulla, K., Rama Rao, C.A., Dixit, Sreenath, Ramana, D.B.V., Venkateswarlu, B. and Ramakrishna, Y.S.. (2007) A Profile of Target Districts in Andhra Pradesh: Demography, Land Use and Agriculture. NAIP-SRL Series-1. Central Research Institute for Dryland Agriculture, Hyderabad. 32 p.

Kaur, Baljinder, Sidhu, R.S. and Vatta, Kamal (2010) Optimum crop plans for sustainable water use in Punjab. Agricultural Economics Research Review, 23 (3):273284.
Gaur, B.L. and Kumawat, S.K. (2004) Evaluating integrated nutrient management and in situ moisture conservation in rainfed maize (Zea mays L.) production system, Indian Journal of Dryland Agriculture Research and Development, 19(1): 91-93.

Mahendran, R., Chandrasekaran, M. and Gurunathan, S. (2006) A study on evolving optimal cropping patterns in groundwater over-exploited region of Perambalur district of Tamil Nadu, Agricultural Economics Research Review, 19(1): 95-108.

Rajendra Poddar, S., Vijaya Kumar, H.S., Shankara Murhty, H.G. and Venkatesh Murthy, T.N. (1996) Impact of credit on cropping pattern and cropping intensity on farms in unirrigated and irrigated villages in Bijapur district of Karnataka - An application of linear programming technique. Agricultural Economics Research Review, 8(1): 29-42.

Rama Rao, C.A., Srinivasa Rao, M., Ramakrishna, Y.S., Vittal, K.P.R. and Reddy, Y.V.R. (2003) Economics of some dryland agricultural technologies. Research Bulletin SDA-1, Central Research Institute for Dryland Agriculture, Hyderabad.

Rama Rao, C.A. and Venkateswarlu, B. (2012) Does dryland agriculture mean the end for a farmer? The Hindu Survey of Indian Agriculture. pp. 57-58.

Sirohi, A.S. and Gangawar, A. C. (1968) Economic optima in resource allocation for the cultivators of Kenjawala block. Indian Journal of Agricultural Economics, 23(3): $1-14$.

Varalakshmi, K. (2007) Optimum crop enterprise mix for the farmers in Panyam mandal of Kurnool district of Andhra Pradesh. MSc Thesis, University of Agricultural Sciences, Dharwad, Karnataka.

Venkateswarlu, B., Ramakrishna, Y.S., Subba Reddy, G., Mayande, V.M., Korwar, G.R. and Prabhakar, M. (2008) Rainfed farming : A profile of doable technologies. Central Research Institute for Dryland Agriculture Technical Bulletin, 48p.

Wani, S.P., Rockstrom, J. and Oweis, T.Y. (2009) Rainfed Agriculture: Unlocking the Potential. CAB International Publishing, United Kingdom.

Revised received: February, 2014; Accepted April, 2014 
Rama Rao et al. : Role of Technology and Credit in Improving Farm Incomes in Rainfed Regions

Appendix Table 1. Farm-size-wise resource use and net returns from different crops in Adilabad district of Andhra Pradesh

(per ha)

\begin{tabular}{|c|c|c|c|c|c|c|}
\hline \multirow[t]{2}{*}{ Crops } & \multicolumn{2}{|c|}{ Capital (₹/ha) } & \multirow{2}{*}{$\begin{array}{c}\text { Family } \\
\text { labour } \\
\text { (human-days /ha) }\end{array}$} & \multirow{2}{*}{$\begin{array}{c}\text { Hired } \\
\text { labour } \\
\text { (human-days /ha) }\end{array}$} & \multicolumn{2}{|c|}{ Net returns (₹/ha) } \\
\hline & $\begin{array}{c}\text { With } \\
\text { technology }\end{array}$ & $\begin{array}{c}\text { Without } \\
\text { technology }\end{array}$ & & & $\begin{array}{c}\text { With } \\
\text { technology }\end{array}$ & $\begin{array}{c}\text { Without } \\
\text { technology }\end{array}$ \\
\hline \multicolumn{7}{|c|}{ Small farmers } \\
\hline Cotton + pigeonpea & 8470 & 9216 & 38 & 30 & 37032 & 4755 \\
\hline Kharif sorghum & 841 & 875 & 40 & 17 & 11447 & 10529 \\
\hline Soybean + pigeonpea & 6018 & 6789 & 36 & 20 & 50666 & 41347 \\
\hline \multicolumn{7}{|c|}{ Medium farmers } \\
\hline Cotton + pigeonpea & 8470 & 8219 & 42 & 13 & 37032 & 36796 \\
\hline Tomato & 5498 & 5550 & 12 & 36 & 66546 & 7754 \\
\hline Leased-out land & & & & & & 2846 \\
\hline \multicolumn{7}{|c|}{ Large farmers } \\
\hline Cotton + pigeonpea & 8470 & 7715 & 36 & 15 & 52713 & 38643 \\
\hline Kharif sorghum & 841 & 1076 & 32 & 13 & 11447 & 17135 \\
\hline Soybean + pigeonpea & 6542 & 6363 & 37 & 20 & 45715 & 48210 \\
\hline
\end{tabular}

Appendix Table 2. Farm-size-wise resource use and net returns from different crops in Rangareddy district of Andhra Pradesh

(per ha)

\begin{tabular}{|c|c|c|c|c|c|c|}
\hline \multirow[t]{2}{*}{ Crops } & \multicolumn{2}{|c|}{ Capital (₹/ha) } & \multirow{2}{*}{$\begin{array}{c}\text { Family } \\
\text { labour } \\
\text { (human-days /ha) }\end{array}$} & \multirow{2}{*}{$\begin{array}{c}\text { Hired } \\
\text { labour } \\
\text { (human-days /ha) }\end{array}$} & \multicolumn{2}{|c|}{ Net returns (₹/ha) } \\
\hline & $\begin{array}{l}\text { With } \\
\text { technology }\end{array}$ & $\begin{array}{c}\text { Without } \\
\text { technology }\end{array}$ & & & $\begin{array}{c}\text { With } \\
\text { technology }\end{array}$ & $\begin{array}{l}\text { Without } \\
\text { technology }\end{array}$ \\
\hline \multicolumn{7}{|c|}{ Small farmers } \\
\hline $\begin{array}{l}\text { Kharif maize }+ \\
\text { pigeonpea }\end{array}$ & 8400 & 8400 & 31 & 39 & 19820 & 19820 \\
\hline Cotton & 8825 & 8825 & 26 & 34 & 66623 & 38123 \\
\hline Kharif rice & 9658 & 9800 & 21 & 45 & 41163 & 11772 \\
\hline Rabi rice & 11000 & 11200 & 54 & 35 & 44047 & 15347 \\
\hline Leased-out land & & & & & 3000 & 3000 \\
\hline \multicolumn{7}{|c|}{ Medium farmers } \\
\hline Cotton & 8494 & 8494 & 20 & 40 & 65422 & 51172 \\
\hline Maize + pigeonpea & 8210 & 8210 & 48 & 25 & 20598 & 20598 \\
\hline Kharif rice & 9491 & 10000 & 76 & 33 & 42158 & 39399 \\
\hline Leased-out land & & & & & 3000 & 3000 \\
\hline \multicolumn{7}{|c|}{ Large farmers } \\
\hline Cotton & 6903 & 6903 & 21 & 24 & 67323 & 45830 \\
\hline Kharif rice & 6056 & 6056 & 20 & 47 & 48942 & 30734 \\
\hline Rabi rice & 5047 & 6047 & 17 & 31 & 54605 & 26195 \\
\hline Kharif maize & 3563 & 3563 & 13 & 17 & 3738 & 13764 \\
\hline $\begin{array}{l}\text { Kharif sorghum + } \\
\text { pigeonpea }\end{array}$ & 2175 & 2175 & 29 & 21 & 85148 & 32273 \\
\hline Leased-out land & & & & & & 3000 \\
\hline
\end{tabular}


Appendix Table 3. Farm-size-wise resource use and net returns from different crops in Mahabubnagar district of Andhra Pradesh

(per ha)

\begin{tabular}{|c|c|c|c|c|c|c|}
\hline \multirow[t]{2}{*}{ Crops } & \multicolumn{2}{|c|}{ Capital (₹/ha) } & \multirow{2}{*}{$\begin{array}{c}\text { Family } \\
\text { labour } \\
\text { (human-days } / \text { ha) }\end{array}$} & \multirow{2}{*}{$\begin{array}{c}\text { Hired } \\
\text { labour } \\
\text { (human-days /ha) }\end{array}$} & \multicolumn{2}{|c|}{ Net returns $(₹ / h a)$} \\
\hline & $\begin{array}{l}\text { With } \\
\text { technology }\end{array}$ & $\begin{array}{c}\text { Without } \\
\text { technology }\end{array}$ & & & $\begin{array}{c}\text { With } \\
\text { technology }\end{array}$ & $\begin{array}{c}\text { Without } \\
\text { technology }\end{array}$ \\
\hline \multicolumn{7}{|c|}{ Small farmers } \\
\hline Cotton & 6365 & 6475 & 34 & 29 & 32814 & 38332 \\
\hline Kharif rice & 5682 & 5825 & 49 & 10 & 46291 & 12911 \\
\hline Rabi sorghum & & 2000 & 41 & 0 & 87767 & 22700 \\
\hline Kharif Leased-out land & & & & & & 1500 \\
\hline \multicolumn{7}{|c|}{ Medium farmers } \\
\hline Kharif maize & 2508 & 2617 & 12 & 7 & 6080 & -4685 \\
\hline Cotton + pigeonpea & 6889 & 5750 & 15 & 22 & 63975 & 55232 \\
\hline Rabi sunflower & 5581 & 7542 & 17 & 15 & 61791 & 47424 \\
\hline Kharif Leased-out land & & & & & & 1500 \\
\hline \multicolumn{7}{|c|}{ Large farmers } \\
\hline Kharif maize & 2125 & 2550 & 20 & 21 & 1420 & 5045 \\
\hline Kharif rice & 4713 & 4713 & 17 & 21 & 41404 & 29636 \\
\hline Cotton + pigeonpea & 7836 & 6878 & 15 & 28 & 61920 & 48506 \\
\hline Rabi groundnut & 3063 & 9806 & 22 & 19 & 14149 & 7406 \\
\hline Kharif Leased-out land & & & & & & 1500 \\
\hline
\end{tabular}

Appendix Table 4. Availability of resources across different categories of farmers in the districts of Adilabad, Mahabubnagar and Rangareddy

\begin{tabular}{|c|c|c|c|}
\hline Resources & Adilabad district & Mahabubnagar district & Rangareddy district \\
\hline \multicolumn{4}{|c|}{ Small farmers } \\
\hline Capital (₹/farm) & 12109 & 10500 & 16580 \\
\hline Family labour (human-days/farm) & 93 & 107 & 52 \\
\hline Hired labour (human-days/farm) & 56 & 39 & 68 \\
\hline Kharif land (ha) & 1.2 & 1.6 & 1.6 \\
\hline Rabi land (ha) & 0 & 0.20 & 0.2 \\
\hline \multicolumn{4}{|c|}{ Medium farmers } \\
\hline Capital (₹/farm) & 22030 & 23691 & 18874 \\
\hline Family labour (human-days/farm) & 87 & 135 & 67 \\
\hline Hired labour (human-days/farm) & 78 & 70 & 81 \\
\hline Kharif land (ha) & 1.6 & 3.20 & 2.2 \\
\hline Rabi land (ha) & 0 & 1.2 & 0 \\
\hline \multicolumn{4}{|c|}{ Large farmers } \\
\hline Capital (₹/farm) & 42431 & 46110 & 31790 \\
\hline Family labour (human-days/farm) & 296 & 330 & 145 \\
\hline Hired labour (human-days/farm) & 134 & 192 & 223 \\
\hline Kharif land (ha) & 2.8 & 7.2 & 5.6 \\
\hline Rabi land (ha) & 0 & 0.80 & 1.6 \\
\hline
\end{tabular}

